\title{
Significance of Arbuscular Mycorrhizal Fungi and Phosphate Dissolving Bacteria to Enhance Phosphate Availability for Barley Plants Grown in Calcareous Soil
}

\author{
Mona M. El-Shazly, Noha M. Abdelhameid and Amr M. Abd El-Gawad ${ }^{1}$
}

\begin{abstract}
Two field experiments were conducted to study the effect of Arbuscular Mycorrhizal fungi (VAM) and phosphate dissolving bacteria (PDB) application on soil phosphate availability to barley plant grown in calcareous soil. The experiments were carried out at experimental research station - Ras Sudr, Desert Research Center in winter seasons of 2015-2016 and 2016-2017. Biofertilizers treatments were: control, Glomus macrocarpium (VAM) and Bacillus megatherium (PDB) either single or mixed application. Phosphorus fertilizers were applied from two sources, mono super phosphate (MSP) and rock phosphate (RP) at rates of 50,75 and $100 \%$ of the recommended dose. Application of MSP fertilizer significantly increase of grain, straw and biological yield during both growing seasons by $2.7,2.1$ and $2.3 \%$, respectively as compared to rock phosphate fertilizer treatment. Dual inoculation with VAM and PDB increased significantly nitrogen and phosphorus concentrations in the grain and straw. The plant height, grain and straw dry weight per plant, 100 grain weight were increased by 7.5, 8.9, 14.8 and $15.8 \%$, respectively and the grain, straw and biological yield increased significantly by $13.4,20.6$ and $18.1 \%$, respectively compared with the un-inoculated treatments. The highest significant biological yield $(5.248 \mathrm{t} / \mathrm{ha})$ was obtained under MSP, 75, VAM+PDB treatments.
\end{abstract}

Key words: barley, salinity, biofertilization, Arbuscular Mycorrhizae Fungi

\section{INTRODUCTION}

here irrigation is feasible and other strategic crops such as wheat can be grown (Ahmed, 2005; Hussein et al., 2009 and Ahmed et al., 2013)

Phosphorus availability in soils can be one of the main factors limiting vegetation growth. Under conditions of limited $\mathrm{P}$, microbes aid in mitigating $\mathrm{P}$ losses and increasing $\mathrm{P}$ availability. Vegetation clearly affects the microbial community and $\mathrm{P}$ cycling (Runyan and D'Odorico, 2013).

The phosphorus content in average soils is about $0.05 \%(\mathrm{w} / \mathrm{w})$ of which only $0.1 \%$ is available to plants (Achal et al. 2007). Nearly $80 \%$ of applied phosphorus may be unavailable to plants (Holford 1997). Global P fertilizer consumption for 2010 was approximately 37.6 Mt with an annual 3\% increase in demand thereafter (Heffer and Prud'homme, 2010). Reserves of mineable rock phosphate (RP), which provide the base raw material for inorganic fertilizer production, are however relatively small and finite (Cordell and White, 2011).

The release of $\mathrm{P}$ adsorbed on the solid phase of the soil into soil solution is very slow, and consequently, phosphorus fertilizer efficiency remains low in calcareous soil (Delgado et al., 2002). The reaction of phosphate in soil has an important contribution to crop growth and fertilizer use efficiency (Sushanta et al., 2014). The availability of $P$ to crops for uptake and utilization is declining in alkaline and calcareous soil due to the decreases of solubility of calcium phosphate minerals (Al Harbi et al., 2013 and Ghafoor, 2016).

Arbuscular mycorrhizal fungi (AMF) are found among the soil flora and interact with approximately $85 \%$ of the plants on the ground (Brachmann and Parniske, 2006). The association known as arbuscular mycorrhiza (AM) offers benefits such as improvements in the physicochemical conditions of soils, reduced erosion and is a component that must be given due consideration in integrated soil management in order to attain profitable levels of productivity without causing agroecosystem deterioration. it is imperative to further the knowledge that allows application of AMF as one of the fertilization technologies employed as part of the establishment and development of plantations in order to reduce the use of chemically synthesized fertilizers.

AM symbiosis can promote host plant growth by increasing the uptake of mineral nutrition such as $\mathrm{P}, \mathrm{Zn}$, and $\mathrm{Cu}$ (Javot et al., 2007). Assessments of spatial and temporal distribution of AM fungi in saline soil show that the abundance of AM fungi is inversely correlated with the level of soil salinity. The number of propagules or the infectivity of fungal isolates decreases with increasing salt (Azcon-Aguilar et al. 2003 and Owen et al., 2015)

Bio-resources is much interchangeable and confusing use of terms such as bio-inoculant, biofertilizer and bio-amendment in the literature. Bioresources can be defined as any organic material applied to soil to improve soil quality, nutrient supply and plant growth. Mechanisms of plant growth promotion include hormone production, improved plant nutrition (mainly $\mathrm{N}$ and $\mathrm{P}$ ). Bacteria promote plant growth through the

${ }^{1}$ Soil Fertility and microbiology Dept.,Desert Research Center

(DRC), Egypt

Received Novmber 19,2017, Accepted December 20, 2017 
production of a variety of stimulating compounds e.g. hormones, antibiotics and enzymes (Gray and Smith, 2005). P improvement mechanisms mediated by bacteria include the production of phosphatases (both alkali and acid), siderophores (Franco-Correa et al., 2010) and lowering of soil $\mathrm{pH}$ through acid secretion. Organisms that specifically mobilise native and legacy soil $\mathrm{P}$ and any insoluble source of $\mathrm{P}$ added (e.g. finely ground RP) are generally referred to as phosphatesolubilizing microorganisms (Jones and Oburger, 2011). Microbial solubilisation of $\mathrm{P}$ is widely thought of as the 'organic acid theory', in which the two mechanisms of $\mathrm{P}$ acquisition involve lowering of $\mathrm{pH}$ (directly dissolving mineral $\mathrm{P}$, by proton extrusion) and/or by the release of organic acid anions that exchange for $\mathrm{P}$ on soil adsorption sites (Oburger et al., 2011 and Zhang et al., 2011).

Biological processes in the soil, such as microbial activity, tend to control the mineralization and immobilization of organic conversion of the insoluble forms of phosphorus to an accessible form by plants (orthophosphate), which is an important trait of phosphate-solubilizing bacteria (PSB) and arbuscular mycorrhizal fungi (AMF) (Fankem et al. 2006, Khan et al. 2007). In the last few years, the development of microbial inoculum containing phosphate-solubilizing microbes (PSM) gained attention of agriculturists (Fasim et al. 2002). Application of PSM, either individually or in combined form, remained successful for increasing yield of soybean, maize, wheat, mung bean and chickpea (Hameeda et al. 2008, Jha et al. 2011, Singh and Prakash 2012 and Minaxi et al. 2013). Sharma et al. (2013) observed increased germination, root and shoot length, fresh weight and proline content of chickpea seedlings by Bacillus sp. and Pseudomonas sp. under osmotic potential of up to $0.4 \mathrm{MPa}$ over uninoculated control. The strains were able to produce IAA and showed $\mathrm{P}$ solubilizing activity. Elkoca et al.
(2010) demonstrated increased $\mathrm{P}, \mathrm{K}$ and micronutrient in common bean as a result of Bacillus and Azospirillum inoculations. In another study, PGPR showed positive effects on plant growth of chickpea (Roopa et al. 2012) resulting in increased number of nodules, root, shoot growth and yield of plant under stress conditions (Egamberdieva et al. 2014).

The objective of this study was to investigate the role of Arbuscular Mycorrhizal Fungi and Phosphate Dissolving Bacteria in increasing availability of phosphate for barley grown in calcareous soil.

\section{MATERIALS AND METHODS}

Two field experiments were carried out at the Agricultural Experimental Station of Desert Research Center (D.R.C.) at Ras Sudr, South Sinai in two successive seasons 2015/2016 and 2016/2017. Seeds of barley (Hordeum vulgare) were sown in the last week of November 2015 and 2016 in plots $(3 \times 3.5 \mathrm{~m})$ in rows. The physical and chemical properties of the soil and irrigation water were determined according to the methods outlined by Page et. al. (1982) and presented in Tables 1 and 2.

\section{Inorganic fertilization:}

Nitrogen and potassium fertilizers were applied at rates of $167 \mathrm{~kg} \mathrm{~N} / \mathrm{ha}$. as $\mathrm{NH}_{4} \mathrm{NO}_{3}(33 \% \mathrm{~N})$ and $107 \mathrm{~kg}$ $\mathrm{K}_{2} \mathrm{O} / \mathrm{ha}$. (48\% $\left.\mathrm{K}_{2} \mathrm{O}\right)$ into three equal doses. At seedling, tillering and heading growth stages. The dose of $10 \mathrm{~m}^{3}$ organic manure was added by mixing with the upper 020 surface layer before seeds sowing.

Phosphate fertilizers were applied from two sources mono super phosphate (MSP) $\left(15.5 \% \mathrm{P}_{2} \mathrm{O}_{5}\right)$ and Rock phosphate, at three $(50,75$ and $100 \%)$ rates of the recommended dose $\left(74 \mathrm{~kg} \mathrm{P}_{2} \mathrm{O}_{5} / \mathrm{ha}\right)$ of the Ministry of Agriculture and Land Reclamation, and mixed with the soil during land preparation.

Table 1.Tthe main physical and chemical properties of the experimental soil (Average of both seasons)

\section{Particle size distribution}

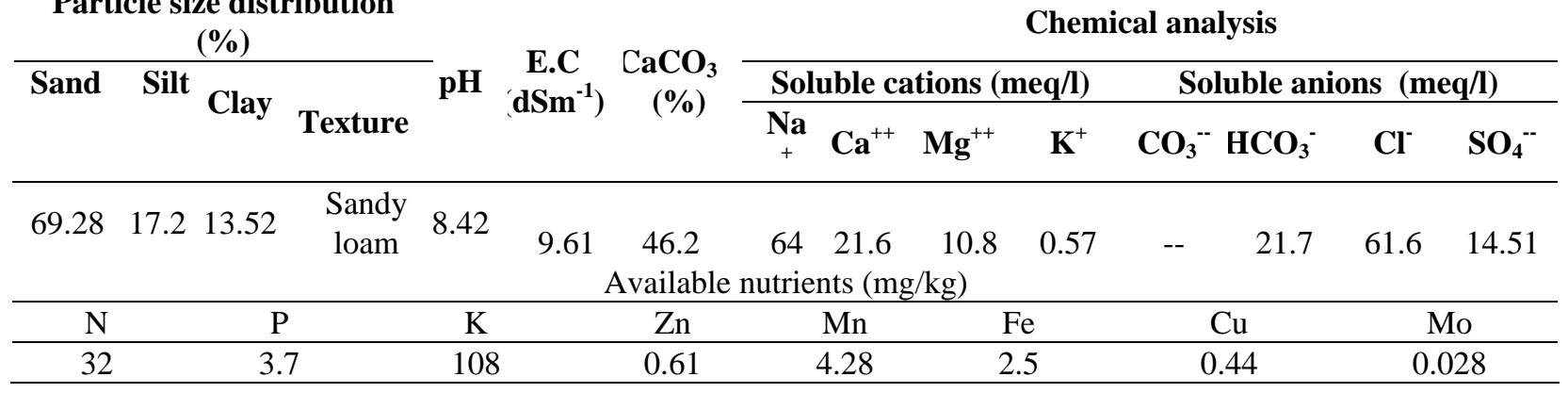

Table 2.The chemical composition of irrigation water

\begin{tabular}{|c|c|c|c|c|c|c|c|c|c|c|}
\hline \multirow{2}{*}{$\mathbf{p H}$} & \multirow{2}{*}{$\begin{array}{c}\mathrm{EC} \\
\left(\mathrm{dSm}^{-1}\right)\end{array}$} & \multicolumn{4}{|c|}{ Soluble cations (meq/l) } & \multicolumn{4}{|c|}{ Soluble anions (meq/l) } & S.A.R \\
\hline & & $\mathrm{Na}^{+}$ & $\mathrm{Ca}^{++}$ & $\mathbf{M g}^{++}$ & $\mathbf{K}^{+}$ & $\mathrm{CO}_{3}^{--}$ & $\mathrm{HCO}_{3}^{-}$ & $\mathrm{Cl}^{-}$ & $\mathrm{SO}_{4}^{--}$ & \multirow{2}{*}{10.4} \\
\hline 7.62 & 8.01 & 48.32 & 25.93 & 5.35 & 0.48 & --- & 2.41 & 58.5 & 20.6 & \\
\hline
\end{tabular}




\section{Biofertilization:}

Separation of Arbuscular Mycorrhizal (VAM): Different spores of mycorrhizae were isolated from soil pre-inoculated with mycorrhiza (Glomus macrocarpium) by wet-sieving and decantation method described by Gerdeman and Nicolson (1963). The VAM inocula was mixed with pure sand and kept in the refrigerator to be used in the inoculation.

Isolation of Phosphate dissolving bacteria (PDB): For isolation of phosphate dissolving bacteria different soil samples were collected from saline soil at different sites of South Sinai. The highest isolate for phosphate solubilization (DeFreitas et al., 1997) were selected for further study. Each isolate was grown on its specific medium containing different sodium chloride concentrations $(2,4,6,8$ and 10\%), also, at different incubation temperatures $\left(25,30,40,45\right.$ and $\left.50^{\circ} \mathrm{C}\right)$ and different $\mathrm{pH}$ values (5-9) and the growth was measured at $600 \mathrm{~nm}$. Selected PDB isolates were purified and identified according to Bergey's manual of determinative bacteriology (1994). The selected isolates (Bacillus megatherium) were subjected to different biochemical tests for screening their hormonal (Rizzolo et al., 1993) and enzymatic activity (Barrow and Veltham, 1993).

Fresh liquid culture of $B$. megatherium was used for single inoculation at the rate of $10^{8}$ colony forming unit $(\mathrm{cfu}) / \mathrm{ml}$ or in combinations with Glomus macrocarpium.

Rhizosphere soil sample were collected at different stages of plant growth and analyzed for: total microbial counts on Bunt and Rovira medium Nautiyal (1999). PDB counts using Pikovskaya's agar medium (PVK) Goenadi et. al., (2000). For the determination of phosphatase activity; disodium phenylphosphate served as enzyme substrate (Öhlinger, 1996).

Assessment of VAM infection: The staining method of Phillips and Hayman (1970) was used for preparing root samples for microscopic observation. The gridlines intersect method of Giovannetti and Mossa (1980) was used to estimate the VAM infection percentage, as follows:

\section{Root colonization $\%=\frac{\text { No. of Positive intersect points }}{\text { Total number of observed intersect points }} \times 100$}

Plant samples and Analysis: Plant samples were taken at harvesting from each treatment, washed by tap water then by distilled water (Chapman and Pratt, 1961), dried at $70{ }^{\circ} \mathrm{C}$, and ground using stainless steel equipment's for the determination of $\mathrm{N}, \mathrm{P}$ and $\mathrm{K}$ as follows: total nitrogen using the micro kjeldahl method
(A.O.A.C,1980), phosphorus, using dry ashing technique according to Cottenie et al. (1982).

Growth parameters: At heading and harvesting stages, the plants were taken from each plot for estimating plant height, fresh and dry weights.

Yield and yield components: At harvest, one square meter from each plot was taken to determine grains, straw and biological yields.

Statistical analysis: The obtained data were exposed to proper statistical analysis of variance according to Gomez and Gomez (1984). LSD at 0.05 level of significance was used for the comparison between means.

\section{RESULTS AND DISCUSSION}

\section{Soil microbial activity:}

\section{PDB counts:}

Table 3 clearly showed that there are high variations of PDB counts between all treatments in barley rhizosphere in both the two successive seasons. The highest PDB counts are recorded with mixed treatment and $100 \%$ mineral phosphate fertilizer (being $92 \times 10^{-2}$ cfu / g dry soil). In the case of rock phosphate, the highest PDB counts are recorded with mixed treatment and $100 \%$ mineral phosphate (being $82 \times 10^{-2}$ cfu / g dry soil). These results agree with those found by Copetta $e t$ al. (2006). Another study showed that the increase of soil phosphorus availability was due to PDB action (Yousufinia et al., 2013).

\section{Phosphatase enzyme:}

Table (3) clearly showed that phosphatase activity recorded significant increase due to mixed biofertilization treatments. Mixed biofertilization treatment with $100 \%$ MSP recorded the highest phosphatase activity (being 0.47 and $0.48 \mathrm{mg}$ phenol/g soil/24h) at the first and second growing season, respectively. In the case of rock phosphate, the highest phosphatase activity was recorded with mixed biofertilization and $100 \%$ rock phosphate (being 0.41 and $0.44 \mathrm{mg}$ phenol/g soil $/ 24 \mathrm{~h}$ ) at the first and second growing season respectively. George et al. (2002) stated that Phosphatase enzyme is able to mineralize organic phosphate into inorganic phosphates that provides high phosphate availability for plant.

\section{Mycorrhizal infection and number of spores:}

The root colonization of barley plants and number of spores / $\mathrm{g}$ soil in the rhizosphere soil were affected by microbial inoculation. The percent of root colonization was higher in the barley inoculated with mixed treatments and $75 \%$ rock phosphate (46.6 and 44.7 in the two seasons for mycorrhizal infection, 14.7 and 14.6 
for number of spores /g soil) compared to noninoculated plants $(6.1$ and 6.8 in the two seasons for mycorrhizal infection, 9.6 and 9.9 for number of spores /g soil).
Mycorrhizal infection and number of spores were increased under rock phosphate treatments by 33.7 and $27.7 \%$ and 5.5 and $3.0 \%$ compared to MSP treatments. Bahadori et al. (2013) found that mixed inoculation have positive effect on increasing root colonization and numbers of VAM spores. These results also agree with

Table 3. Effect of biofertilizers application, mineral and rock phosphate on microbial activity in rhizosphere of Barley plant grown in the two seasons

\begin{tabular}{|c|c|c|c|c|c|c|c|c|c|c|}
\hline \multirow{2}{*}{$\mathbf{P}$} & \multirow{2}{*}{ Dose* } & \multirow{2}{*}{ Bio } & \multicolumn{2}{|c|}{$\begin{array}{c}\text { Mycorrhizal } \\
\text { Infection (\%) }\end{array}$} & \multicolumn{2}{|c|}{$\begin{array}{c}\text { Mycorrhiza No. of } \\
\text { spore/g soil }\end{array}$} & \multicolumn{2}{|c|}{$\frac{\text { PDB counts }}{\left(\times 10^{2} \mathrm{cfu} / \mathrm{g} \text { dry soil }\right)}$} & \multicolumn{2}{|c|}{$\begin{array}{c}\text { Phosphatase enzyme } \\
\text { (mg phenol/g soil/24h) }\end{array}$} \\
\hline & & & $\begin{array}{c}1^{\text {st }} \\
\text { season }\end{array}$ & $\begin{array}{c}2^{\text {nd }} \\
\text { season }\end{array}$ & $\begin{array}{c}1^{\text {st }} \\
\text { season }\end{array}$ & $2^{\text {nd }}$ season & $\begin{array}{c}1^{\text {st }} \\
\text { season }\end{array}$ & $\begin{array}{c}2^{\text {nd }} \\
\text { season }\end{array}$ & $\begin{array}{c}1^{\text {st }} \\
\text { season }\end{array}$ & $\begin{array}{c}2^{\text {nd }} \\
\text { season }\end{array}$ \\
\hline \multirow{18}{*}{ MSP } & \multirow{5}{*}{50} & Control & 6.1 & 6.8 & 9.6 & 9.9 & 24 & 29 & 0.11 & 0.12 \\
\hline & & VAM & 31.9 & 33.2 & 13.7 & 14.2 & 53 & 64 & 0.29 & 0.35 \\
\hline & & PDB & 8.6 & 10.1 & 9.8 & 10.1 & 69 & 76 & 0.34 & 0.36 \\
\hline & & $\mathrm{VAM}+\mathrm{PDB}$ & 33.1 & 33.4 & 13.9 & 14.4 & 77 & 79 & 0.37 & 0.40 \\
\hline & & mean & 19.9 & 20.9 & 11.8 & 12.2 & 56 & 62 & 0.28 & 0.31 \\
\hline & \multirow{5}{*}{75} & Control & 8.2 & 7.3 & 9.4 & 9.7 & 25 & 32 & 0.15 & 0.16 \\
\hline & & VAM & 25.4 & 27.9 & 13.5 & 14.0 & 57 & 66 & 0.33 & 0.36 \\
\hline & & PDB & 7.9 & 8.8 & 9.7 & 10.1 & 71 & 74 & 0.35 & 0.38 \\
\hline & & $\mathrm{VAM}+\mathrm{PDB}$ & 26.7 & 28.1 & 13.8 & 14.3 & 78 & 81 & 0.42 & 0.44 \\
\hline & & mean & 17.1 & 18.0 & 11.6 & 12.0 & 58 & 63 & 0.31 & 0.34 \\
\hline & \multirow{5}{*}{100} & Control & 7.2 & 7.9 & 8.9 & 9.2 & 28 & 33 & 0.16 & 0.19 \\
\hline & & VAM & 17.3 & 19.8 & 13.4 & 13.6 & 52 & 61 & 0.35 & 0.39 \\
\hline & & PDB & 7.6 & 8.1 & 9.8 & 10.1 & 65 & 73 & 0.39 & 0.41 \\
\hline & & VAM+PDB & 18.9 & 21.2 & 13.4 & 14.0 & 80 & 92 & 0.47 & 0.48 \\
\hline & & mean & 12.8 & 14.3 & 11.4 & 11.7 & 56 & 65 & 0.34 & 0.37 \\
\hline & \multirow{7}{*}{50} & mean & 16.6 & 17.7 & 11.6 & 12.0 & 57 & 63 & 0.31 & 0.34 \\
\hline & & Control & 8.2 & 8.9 & 10.1 & 10.3 & 21 & 23 & 0.13 & 0.15 \\
\hline & & VAM & 43.7 & 43.1 & 14.5 & 14.4 & 42 & 49 & 0.22 & 0.25 \\
\hline \multirow{12}{*}{$\mathrm{RP}$} & & PDB & 11.2 & 12.1 & 10.4 & 10.5 & 56 & 63 & 0.28 & 0.32 \\
\hline & & VAM+PDB & 46.6 & 44.7 & 14.7 & 14.6 & 73 & 78 & 0.31 & 0.34 \\
\hline & & mean & 27.4 & 27.2 & 12.43 & 12.45 & 48 & 53 & 0.24 & 0.27 \\
\hline & & Control & 8.2 & 9.1 & 9.9 & 10.0 & 24 & 29 & 0.14 & 0.17 \\
\hline & \multirow{4}{*}{75} & VAM & 35.4 & 33.6 & 14.3 & 14.5 & 52 & 63 & 0.27 & 0.3 \\
\hline & & PDB & 10.3 & 11.1 & 10.2 & 10.3 & 64 & 75 & 0.35 & 0.36 \\
\hline & & VAM+PDB & 35.4 & 36.1 & 14.5 & 14.6 & 70 & 76 & 0.39 & 0.43 \\
\hline & & mean & 22.3 & 22.5 & 12.2 & 12.4 & 53 & 61 & 0.29 & 0.32 \\
\hline & \multirow{5}{*}{100} & Control & 7.9 & 8.1 & 9.4 & 9.5 & 27 & 29 & 0.17 & 0.19 \\
\hline & & VAM & 24.5 & 27.2 & 14.1 & 14.3 & 55 & 58 & 0.28 & 0.31 \\
\hline & & PDB & 8.3 & 9.1 & 10.3 & 10.5 & 63 & 70 & 0.37 & 0.42 \\
\hline & & VAM+PDB & 26.4 & 28.1 & 14.2 & 14.4 & 74 & 82 & 0.41 & 0.44 \\
\hline \multirow{5}{*}{\multicolumn{2}{|c|}{$\mathrm{LSD}_{0.05}$}} & mean & 16.8 & 18.1 & 12.0 & 12.2 & 55 & 60 & 0.31 & 0.34 \\
\hline & & mean & 22.2 & 22.6 & 12.2 & 12.3 & 52 & 58 & 0.28 & 0.31 \\
\hline & & Bio & 0.05 & 0.05 & 0.03 & 0.03 & 0.12 & 0.13 & 0.0006 & 0.0007 \\
\hline & & Dose & 0.04 & 0.04 & 0.02 & 0.02 & 0.10 & 0.11 & 0.0005 & 0.0006 \\
\hline & & $\mathrm{P}$ & 0.03 & 0.03 & 0.02 & 0.02 & 0.08 & 0.09 & 0.0005 & 0.0005 \\
\hline
\end{tabular}

(MSP) mono superphosphate, $(\mathrm{RP})$ rock phosphate, $\left({ }^{*}\right)$ Percentage of recommended dose 
Table 4. Effect of biofertilizers application, mineral and rock phosphate on macronutrients content of grain and straw of barley

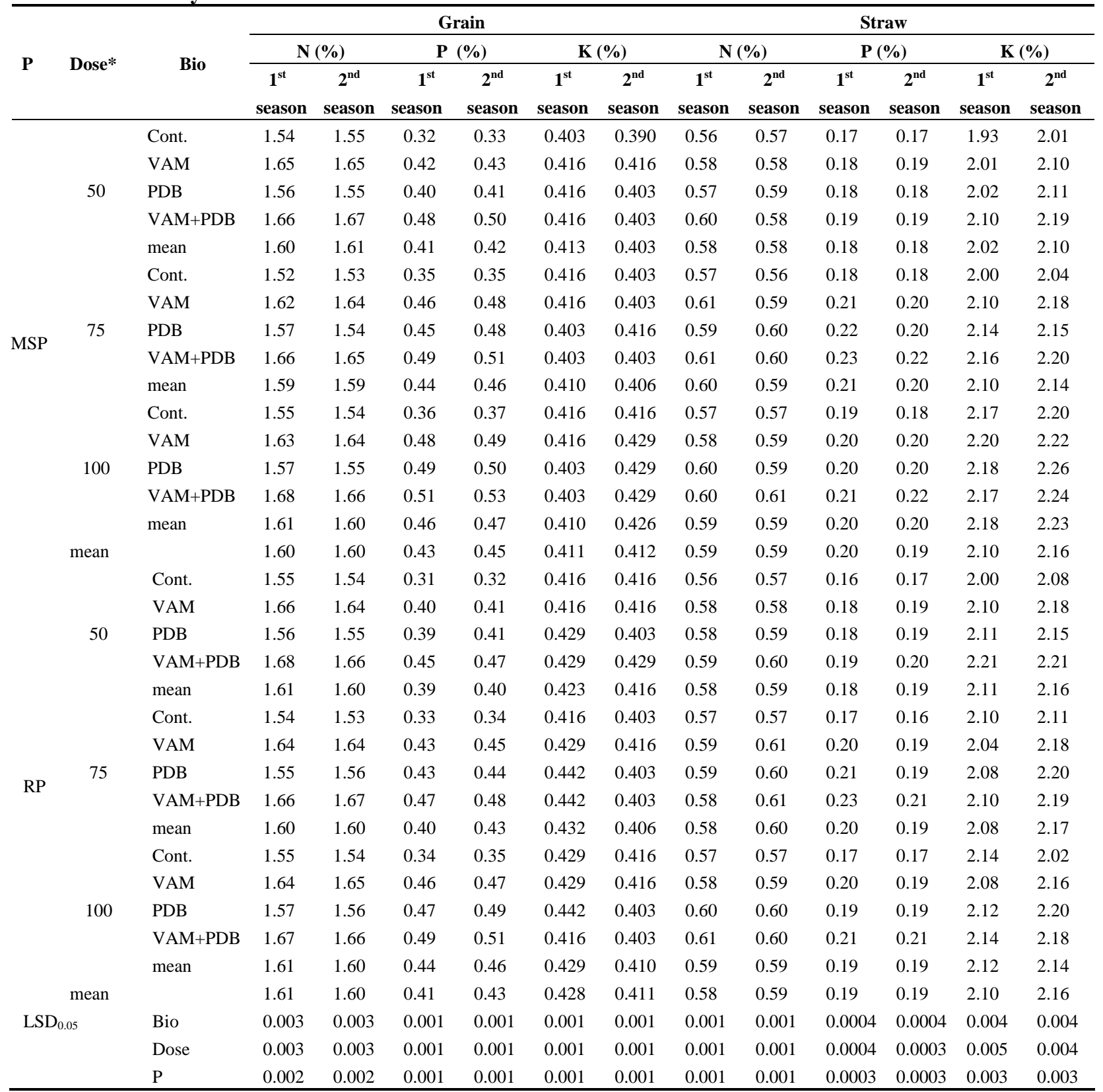

(MSP) mono super phosphate, $(\mathrm{RP})$ rock phosphate, $(*)$ Percentage of recommended dose

the earlier findings of Garbaye (1994) who reported that bacteria, such as those of genus bacillus, produce phytohormones and cohabit in the rhizosphere with VAM fungi which could stimulate the plant-fungus interaction.

\section{Nutrient concentration:}

Table (4) showed that N, P and K percentages in barley grains and straw were markedly influenced by biofertilization treatments, mineral and rock phosphate application. The highest $\mathrm{N}, \mathrm{P}$ and $\mathrm{K}$ concentrations were recorded in mixed biofertilization and MSP at $100 \%$ of recommended rate (being 1.66, 0.53 and $0.43 \%$ for total $\mathrm{N}, \mathrm{P}$ and $\mathrm{K}$ in grain, respectively at the second season). These results are in agreement with those found by Teakle and Tyerman (2010). Inoculation with AMF+PDB significantly increased the nitrogen

concentration in grain and straw in both seasons compared to other biological treatments. At the same time, $\mathrm{N}$ concentration in grain and straw were increased by $8.4,8.5 \%$ and $5.64,5.68 \%$ in the two seasons, respectively compared to the control treatment. While $\mathrm{N}$ 
concentration was not significantly affected by phosphorus types or dose treatments, the highest significant $\mathrm{P}$ concentrations in grain and straw were recorded under MSP, $100 \%$ of recommended dose, and $\mathrm{VAM}+\mathrm{PDB}$ treatments in two seasons. On contrast, $\mathrm{K}$ concentration was not significantly affected by application $\mathrm{P}$ or biological treatments. Farzaneh et al. (2011) and Wang et. al. (2015) stated that AMF colonize roots of host plants and promote plant growth due to improved uptake of nutrients.

\section{Growth Parameters:}

Data illustrated in Table (5) showed a significant difference due to biofertilizers (VAM and PDB), MSP and rock phosphate treatments on the growth parameters of barley plant. Application of MSP fertilizer significantly increase plant height, grain dry weight and straw dry weight per plant and 100 grain weight during both growing seasons by 1.2, 5.2, 1.7 and $5.0 \%$ compared to rock phosphate fertilizer treatment, respectively. Simultaneous application of $100 \%$ of the recommended dose of $\mathrm{P}$ fertilizer produced the highest growth parameters. Dual inoculation with (VAM and) PDB had the highest enhancement effect on the growth parameters and increased significantly the plant height, grain and straw dry weight per plant, 100 grain weight by $7.5,8.9,14.8$ and $15.8 \%$ when compared with uninoculated treatments, respectively. At the same time, single inoculation with (VAM) or (PDB) increased significantly the all plant growth parameters by 5.4 and $5.1 \%, 6.9$ and $6.4 \%, 13.0$ and $11.5 \%$, and 11.2 and $9.1 \%$ due to VAM and PDB, respectively as compared to un-inoculated treatments. Shaalan (2005) reported that inoculated seeds with bio-fertilizer such as Azospirillum, Azotobacter and Pseudomonas gave better plant growth due to the increased nutrients uptake by plant. Microbial inoculation also led to improving soil attributes such as organic matter content and increased P content. Zahir et al. (1998), Shaukat et al. (2006b), Nourinia et al. (2007) and Xu et al. (2010) reported an increase of plant height of corn and barley by applying VAM, Azotobacter and Pseudomonas.

\section{Yield Parameters:}

The impact of various treatments on barley yield parameters (grain, straw and biological yield) was shown in Table (6). Data showed a significant difference for biofertilizers (VAM and $P D B$ ), MSP and rock phosphate treatments on the yield parameters of barley plant. Application of MSP fertilizer significantly increase grain, straw and biological yield during both growing seasons by $2.7,2.1$ and $2.3 \%$, respectively compared to rock phosphate fertilizer treatment. At the same time, application of $100 \%$ of recommended dose of $\mathrm{P}$ fertilizer produce the highest yield parameters. Dual inoculation with VAM and PDB had the highest enhancement effect on yield parameters and increased significantly the grain, straw and biological yield by $13.4,20.6$ and $18.1 \%$ when compared with uninoculated treatments. On the other hand, single inoculation with VAM or PDB increased significantly the all yield parameters by 8.9 and $5.5 \%, 13.4$ and $8.2 \%$, and 11.8 and $7.3 \%$ for VAM and PDB, respectively as compared to un-inoculated treatments. the microbial inoculation increased plant growth and yield parameters especially in cereals, by producing growth promoting nutrients and improving soil attributes such as organic matter content and increased nutrients content. The obtained results are in agreement with those found by Mousavi and Seghatoleslami (2011) and Rahim et al. (2013).

Generally, comparing means of biological yield of barley are shown in Fig. (1). The highest significant biological yield (5.248 t/ha) was obtained with MSP, 75 , VAM+PDB treatments while the lowest biological yield (4.153 t/ha) was recorded under RP,50, control. No significant differences of biological yield was observed between each of RP,75, VAM+PDB and MSP, 50, VAM+PDB; MSP, 100, PDB and MSP, 75, VAM; RP, 100, PDB and RP, 100, VAM; MSP, 50, PDB and RP, 50, PDB. Inoculated seeds of barley with VAM or PDB increased the solubility of phosphorus in soil and produced plant promoting materials which lead to increase plant growth and yield parameters.

\section{CONCLUSION}

This study was conducted to investigate the role of microbial inoculation with VAM and PDB on the concentration of $\mathrm{N}, \mathrm{P}$ and $\mathrm{K}$ in barley plants, growth parameters and yield of barley grown in calcareous soil conditions. It can be concluded that application of MSP fertilizer significantly increase grain, straw and biological yield compared to rock phosphate fertilizer. Dual inoculation with VAM and PDB increased significantly nitrogen and phosphorus concentration in grain and straw. Also the plant height, grain and straw dry weight per plant and 100 grain weight and increased significantly the grain, straw and biological yield when compared with un-inoculated treatments. The highest significant biological yield was obtained under MSP, 75 , VAM+PDB treatments. Using microbial inoculation would reduce inorganic chemical fertilizers and reduce the environmental pollution, simultaneously, to give a sustainable and productive agricultural system in the long term. 
Table 5. Effect of biofertilizers, mineral and rock phosphate application on the growth parameters of Barley grown in the two seasons

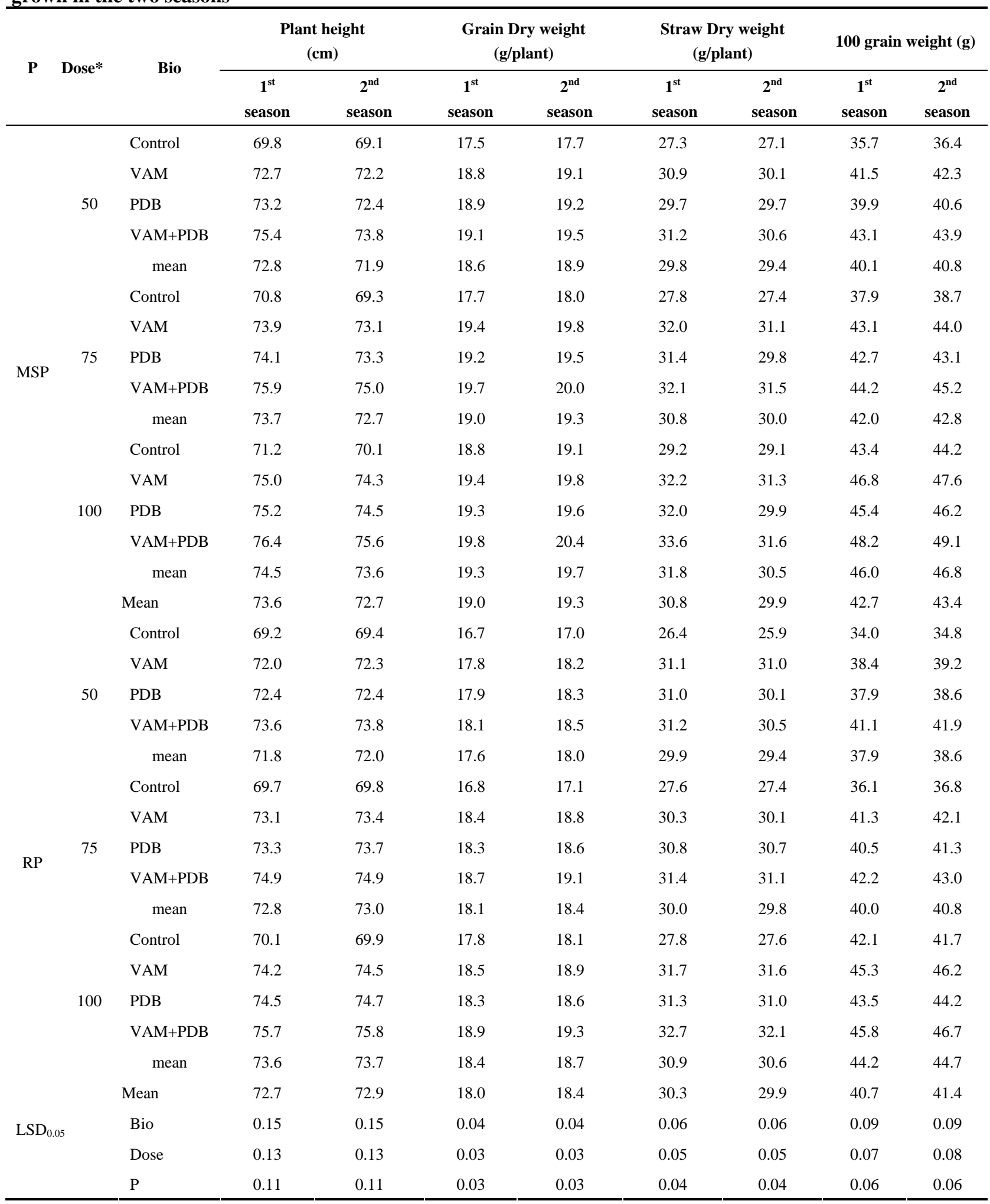

(MSP) mono super phosphate, $(\mathrm{RP})$ rock phosphate, $(*)$ Percentage of recommended dose 
Table 6. Effect of biofertilizers application, mineral and rock phosphate on yield parameters of Barley grown in the two seasons

\begin{tabular}{|c|c|c|c|c|c|c|c|c|c|c|c|}
\hline \multirow[b]{2}{*}{$\mathbf{P}$} & \multirow[b]{2}{*}{ Dose* } & \multirow[b]{2}{*}{ Bio } & \multicolumn{3}{|c|}{ Grain yield (t/ha) } & \multicolumn{3}{|c|}{ Straw yield (t/ha) } & \multicolumn{3}{|c|}{ Biological Yield (t/ha) } \\
\hline & & & $\begin{array}{c}1^{\text {st }} \\
\text { season }\end{array}$ & $\begin{array}{c}2^{\text {nd }} \\
\text { season }\end{array}$ & mean & $\begin{array}{c}1^{\text {st }} \\
\text { season }\end{array}$ & $\begin{array}{c}2^{\text {nd }} \\
\text { season }\end{array}$ & mean & $\begin{array}{c}1^{\text {st }} \\
\text { season }\end{array}$ & $\begin{array}{c}2^{\text {nd }} \\
\text { season }\end{array}$ & mean \\
\hline \multirow{18}{*}{ MSP } & \multirow{5}{*}{50} & Control & 1.476 & 1.499 & 1.488 & 2.737 & 2.808 & 2.773 & 4.213 & 4.308 & 4.260 \\
\hline & & VAM & 1.595 & 1.642 & 1.618 & 3.070 & 3.094 & 3.082 & 4.665 & 4.736 & 4.701 \\
\hline & & PDB & 1.523 & 1.547 & 1.535 & 2.832 & 2.904 & 2.868 & 4.355 & 4.451 & 4.403 \\
\hline & & VAM+PDB & 1.666 & 1.714 & 1.690 & 3.284 & 3.356 & 3.320 & 4.950 & 5.069 & 5.010 \\
\hline & & mean & 1.565 & 1.601 & 1.583 & 2.981 & 3.040 & 3.011 & 4.546 & 4.641 & 4.593 \\
\hline & \multirow{5}{*}{75} & Control & 1.476 & 1.523 & 1.499 & 2.666 & 2.808 & 2.737 & 4.141 & 4.332 & 4.236 \\
\hline & & VAM & 1.642 & 1.690 & 1.666 & 3.165 & 3.237 & 3.201 & 4.808 & 4.927 & 4.867 \\
\hline & & PDB & 1.547 & 1.571 & 1.559 & 2.975 & 2.999 & 2.987 & 4.522 & 4.570 & 4.546 \\
\hline & & VAM+PDB & 1.737 & 1.761 & 1.749 & 3.451 & 3.546 & 3.499 & 5.188 & 5.307 & 5.248 \\
\hline & & mean & 1.601 & 1.636 & 1.618 & 3.064 & 3.148 & 3.106 & 4.665 & 4.784 & 4.724 \\
\hline & \multirow{5}{*}{100} & Control & 1.499 & 1.523 & 1.511 & 2.785 & 2.832 & 2.808 & 4.284 & 4.355 & 4.320 \\
\hline & & VAM & 1.666 & 1.714 & 1.690 & 3.237 & 3.308 & 3.273 & 4.903 & 5.022 & 4.962 \\
\hline & & PDB & 1.642 & 1.642 & 1.642 & 3.189 & 3.284 & 3.237 & 4.831 & 4.927 & 4.879 \\
\hline & & VAM+PDB & 1.737 & 1.737 & 1.737 & 3.380 & 3.451 & 3.415 & 5.117 & 5.188 & 5.153 \\
\hline & & mean & 1.636 & 1.654 & 1.645 & 3.148 & 3.219 & 3.183 & 4.784 & 4.873 & 4.828 \\
\hline & \multirow{7}{*}{50} & Mean & 1.601 & 1.630 & 1.615 & 3.064 & 3.136 & 3.100 & 4.665 & 4.766 & 4.715 \\
\hline & & Control & 1.428 & 1.452 & 1.440 & 2.666 & 2.761 & 2.713 & 4.094 & 4.213 & 4.153 \\
\hline & & VAM & 1.571 & 1.571 & 1.571 & 3.023 & 3.094 & 3.058 & 4.593 & 4.665 & 4.629 \\
\hline \multirow{12}{*}{$\mathrm{RP}$} & & PDB & 1.523 & 1.547 & 1.535 & 2.808 & 2.904 & 2.856 & 4.332 & 4.451 & 4.391 \\
\hline & & VAM+PDB & 1.618 & 1.642 & 1.630 & 3.118 & 3.142 & 3.130 & 4.736 & 4.784 & 4.760 \\
\hline & & mean & 1.535 & 1.553 & 1.544 & 2.904 & 2.975 & 2.939 & 4.439 & 4.528 & 4.483 \\
\hline & & Control & 1.499 & 1.523 & 1.511 & 2.737 & 2.832 & 2.785 & 4.236 & 4.355 & 4.296 \\
\hline & \multirow{4}{*}{75} & VAM & 1.571 & 1.571 & 1.571 & 3.070 & 3.118 & 3.094 & 4.641 & 4.689 & 4.665 \\
\hline & & PDB & 1.523 & 1.547 & 1.535 & 2.904 & 2.927 & 2.916 & 4.427 & 4.474 & 4.451 \\
\hline & & VAM+PDB & 1.666 & 1.690 & 1.678 & 3.308 & 3.356 & 3.332 & 4.974 & 5.046 & 5.010 \\
\hline & & mean & 1.565 & 1.583 & 1.574 & 3.005 & 3.058 & 3.032 & 4.570 & 4.641 & 4.605 \\
\hline & \multirow{4}{*}{100} & Control & 1.499 & 1.499 & 1.499 & 2.808 & 2.856 & 2.832 & 4.308 & 4.355 & 4.332 \\
\hline & & VAM & 1.618 & 1.642 & 1.630 & 3.142 & 3.189 & 3.165 & 4.760 & 4.831 & 4.796 \\
\hline & & PDB & 1.618 & 1.642 & 1.630 & 3.142 & 3.165 & 3.154 & 4.760 & 4.808 & 4.784 \\
\hline & & VAM+PDB & 1.642 & 1.666 & 1.654 & 3.356 & 3.427 & 3.392 & 4.998 & 5.093 & 5.046 \\
\hline \multirow{5}{*}{\multicolumn{2}{|c|}{$\mathrm{LSD}_{0.05}$}} & mean & 1.595 & 1.612 & 1.604 & 3.112 & 3.159 & 3.136 & 4.706 & 4.772 & 4.739 \\
\hline & & Mean & 1.565 & 1.583 & 1.574 & 3.007 & 3.064 & 3.035 & 4.572 & 4.647 & 4.609 \\
\hline & & Bio & 0.003 & 0.003 & 0.003 & 0.006 & 0.006 & 0.006 & 0.01 & 0.01 & 0.001 \\
\hline & & Dose & 0.003 & 0.003 & 0.003 & 0.005 & 0.006 & 0.006 & 0.008 & 0.008 & 0.008 \\
\hline & & $\mathrm{P}$ & 0.002 & 0.002 & 0.002 & 0.004 & 0.005 & 0.006 & 0.007 & 0.007 & 0.007 \\
\hline
\end{tabular}




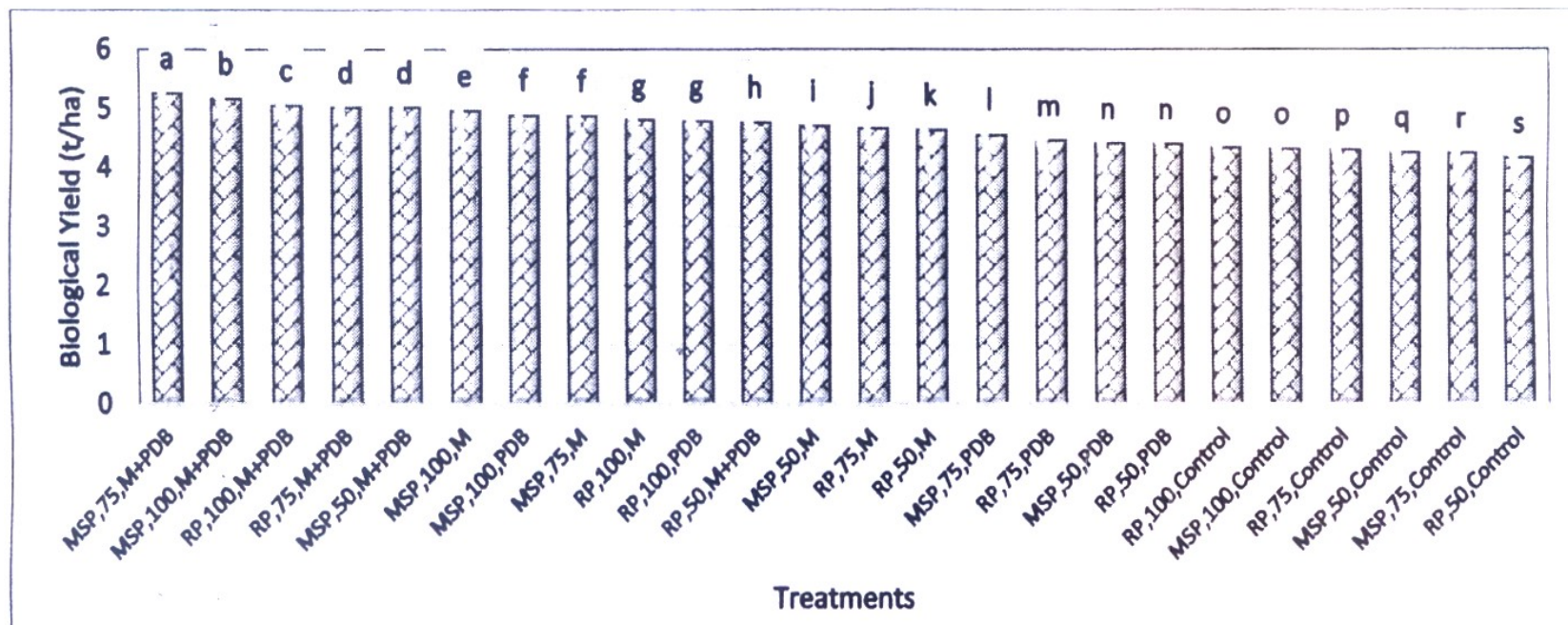
$(\mathrm{M})=\mathrm{VAM}$

Fig. 1. Effect of applied $P$, dose and biological treatments on average Biological yield of Barley.

\section{REFERENCES}

A.O.A.C., 1980. Association Official Agricultural Chemists. "Official Methods of Analysis", $13^{\text {th }}$ Ed.,Washington, D. G., U.S.A.

Achal, V., V.V. Savant and R.M. Sudhakara. 2007. Phosphate solubilization by wide type strain and UV-induced mutants of Aspergillus tubingensis. Soil Biol. Biochem. 39:695-699

Ahmed, I.A. 2005. Highlights of the Barley Breeding Program in Egypt. In: Grando S. and H.G. Macpherson (Ed.) Food Barley: Importance, Uses and Local Knowledge. Inter. Center Agric. Res. in the Dry Areas.

Ahmed, M.A., A.F. Magda, Shalaby and E. A. El-Housini. 2013. Partition and migration of photosynthetes in newly cultivated barley (Horeteum vulgare L.) grown under sandy soil in Egypt. J. of Applied Sci. Res. 9(3): 21602169.

Al-Harbi S.F., A.M. Ghoneim, A.S. Modaihsh and M.O. Mahjoub. 2013. Effect of Foliar and Soil Application of Phosphorus on Phosphorus Uptake, Use Efficiency and Wheat Grain Yield in Calcareous Soil. J. Appl. Sci. 13(1):188-192.

Azcon-Aguilar C., J. Palenzuela, A. Roldan, S. Bautista, R. Vallejo and J.M. Barea .2003. Analysis of the mycorrhizal potential in the rhizosphere of representative plant species from desertification threatened mediterranean shrublands. Appl. Soil Ecol. 22:29-37

Bahadori F., E.S. Ashorabadi, M. Mirzam, M. Matinizade and V. Abdosi. 2013. Improved growth, essential oil yield and quality in Thymus daenensis Celak on mycorrhizal and plant growth promoting rhizobacteria inoculation. Int. J. Agron. Prod. 4 (12), 3384-3391.

Barrow G.L. and R.K.A. Velthan. 1993. Mannual for the Identification of Medical Bacteria. Cambridge Univ.Press.

Bergey's Manual of Determinative Bacteriology 1994. John G. Hol, Noel R. Kriey, Peter H.A. Sneath, James T. Staley
T.Williams $\left(9^{\text {th }}\right.$ ed.) Williams and Wilkins, Baltimore London.

Brachmann, A. and M. Parniske. 2006. The most widespread symbiosis on earth. PLoSBiol. 4: 239-240. doi:http://dx.doi.org/10.1371/journal.pbio.0040239.

Chapman, H. and A. Pratt. 1961. Methods of analysis for soil, water and plants. Reverside, California, U.S.A.

Copetta A., G. Lingua, G. Berta. 2006. Effects of three AM fungi on growth, distribution of glandular hairs, and essential oil production of Ocimumbasilicum L. var. Genovese. Mycorrhiza 16, 485-494.

Cordell, D. and S. White. 2011. Peak phosphorus: clarifying the key issues of a vigorous debate about long-term phosphorus security. Sustainability. : 2027-2049.

Cottenie A., M. Verloo, L. Kiekens, G. Velgh and R. Camerlynch. 1982. Chemical analysis of plants and soils, Lab, annal. agrochem. State Univ. Ghent Belgium, 63.

DeFreitas J. R., M.R. Banerjee and J.J. Germida. 1997. Phosphate solubilizing rhizobacteria enhance the growth and yield but not phosphorus uptake of canola (Brassica napus L.). Biol. Fertil. Soils, 24: 358-364.

Delgado A., I. Uceda, L. Andreu and S. Kassem. 2002. Fertilizer phosphorus recovery from gypsum-amended reclaimed calcareous marsh soils. Arid Land Res. Manag. 16: 319-334.

Egamberdieva D., V. Shurigin, S. Gopalakrishnan and R. Sharma. 2014. Growth and symbiotic performance of chickpea (Cicer arietinum) cultivars under saline soil conditions. J. Biol. Chem. Res. 31: 333-341.

Elkoca E., M. Turan and M.F. Donmez. 2010. Effects of single, dual and triple inoculations with Bacillus subtilis, Bacillus megaterium and Rhizobium leguminosarum bv. phaseoli on nodulation, nutrient uptake, yield and yield parameters of common bean (Phaseolus vulgaris L.). J. Plant Nutr. 33: 2104-2119. 
Fankem H., A. Nwaga, A. Dueubel, L. Dieng, W. Merbach and F.X. Etoa. 2006. Occurrence and functioning of phosphate solubilizing microorganisms from oil palm tree (Elaeis guineensis) rhizosphere in Cameroon. Afr. J. Biotechnol. 5: 2450-2460.

Farzaneh M., H. Vierheilig, A. L?ssl and H.P. Kaul. 2011. Arbuscular mycorrhiza enhances nutrient uptake in chickpea. Plant Soil Environ., 57 (10): 465-470.

Fasim F., N. Ahmed, R. Parsons and G.M. Gadd. 2002. Solubilization of zinc salts by a bacterium isolated from the air environment of a tannery. FEMS Microbiol Lett. 213: 1-6.

Franco-Correa, M., A. Quintana, C. Duque, C. Suarez, M.X. Rodr?guez and J. Barea. 2010. Evaluation of actinomycete strains for key traits related with plant growth promotion and mycorrhiza helping activities. Appl. Soil Ecol. 45: 209-217.

Garbaye J. 1994. Helper bacteria: a new dimension to the mycorrhizal symbiosis. New Phytol. 128, 197-210.

George, T. S., P. J. Gregory, M. Wood, D. Read and R. J. Buresh. (2002). Phosphates activity and organic acids in the rhizosphere of potential agro forestry species and maize. Soil Biol.Biochem., 34: 1487-1494.

Gerdeman, J.W. and T.H. Nicolson. 1963. Spores of mycorrhizal Endogone species extracted from soil by wet sieving and decanting. Trans.Br.Mycol.Soc. 64:235-244.

Ghafoor, A.M.R. 2016. Effect of Phosphorus Fertilizer Application on Some Yield Components of Wheat and Phosphorus Use Efficiency in Calcareous Soil. J. Dynam. Agric. Res. 3(4): 46-52.

Giovannetti, M. and B. Mossa. 1980. An evaluation of techniques for measuring vesicular - arbuscular mycorrhizal infection in roots. New Phytol. 84: 489-500.

Goenadi D.H., Y. Siswanto and Y. Sugiarto. 2000. OSoil science society of America journal, 64:927-932.

Gomez, K. A. and A. A. Gomez. 1984. Statistical Procedures for Agriculture Research. A Wiley- Inter Science Publication, John Wiley \& Sons, Inc. New York, USA.

Gray, E.J. and D.L. Smith. 2005. Intracellular and extracellular PGPR: commonalities and distinctions in the plant-bacterium signaling processes. Soil Biol. Biochem. 37: 395-412.

Hameeda B., G. Harini, O.P. Rupela, S.P. Wani and G. Reddy. 2008. Growth promotion of maize by phosphatesolubilizing bacteria isolated from composts and macrofauna. Microbiol. Res. 163:234-242.

Heffer P. and Prud'homme. 2010. Fertilizer outlook 20102014. $78^{\text {th }}$ IFA Annual Conference Paris IFA, France, 31 May-2 June 2010.

Holford I.C.R. 1997. Soil phosphorus: its measurement, and its uptake by plants. Aust. J. Soil Res. 35: 227-239.

Hussein, M.M., E.M. Okasha, E. S. Soliman and A.A. Aboellil. 2009. Productivity of some barley cultivars under water deficit. Egypt. J. of Appl. Sci. 24(9): 101-115.
Javot, H., N. Pumplin and M.J. Harrison. 2007. Phosphate in the arbuscular mycorrhizal symbiosis: transport properties and regulatory roles. Plant Cell Environ. 30: 310-322.

Jha A., D. Sharma and J. Saxena. 2011. Effect of single and dual phosphate solubilizing bacterial strain inoculations on overall growth of mung bean plants. Arch. Agron. Soil. Sci. 58: 967-981.

Jones, D. and E. Oburger. 2011. Solubilization of phosphorus by soil microorganisms. In: Bunemann, E., A. Oberson and E. Frossard (Eds.) Phosphorus in Action: Biological Processes in Soil Phosphorus Cycling, 26. Springer. 169198.

Khan M.S., A. Zaidi and P.A. Wani. 2007. Role of phosphatesolubilizing microorganisms in sustainable agriculture-a review. Agron. Sustain. Dev. 27: 29-43.

Minaxi S.J., S. Chandra and L. Nain. 2013. Synergistic effect of phosphate solubilizing rhizobacteria and arbuscular mycorrhiza on growth and yield of wheat plants. J. Soil Sci. Plant Nutr. 13: 511-525.

Mousavi S.G.R. and M.J. Seghatoleslami. 2011. Effect of different chemical and bio-fertilizers on morphological traits, yield and yield components of barley. Advances in Environmental Biology, 5 (10): 3312-3317.

Nautiyal C.S. 1999. An efficient microbiological growth medium for screening phosphate solubilizing microorganisms. FEMS Microbiology Letters. 170: 265270.

Nourinia Abas-Ali, Faghani Elham , Rejali Farhad, Safarnezhad Atieh and Abbasi Mohammad-Reza , 2007. Evaluation Effects of Symbiosis of Mychorrhiza on Yield Components and Some Physiological Parameters of Barley Genotypes Under Salinity Stress. Asian J. Plant Sci., 6: 1108-1112.

Oburger, E., D.L. Jones and W.W. Wenzel. 2011. Phosphorus saturation and $\mathrm{pH}$ differentially regulate the efficiency of organic acid anion-mediated $\mathrm{P}$ solubilization mechanisms in soil. Plant Soil. 341: 363-382.

Öhlinger, R.1996. Phosphomonoesterase activity with the substrate phenylphosphate. In: Schinner, F.,Öhlinger, R., Kandeler, E., Margesin, R., (eds.) Methods in Soil Biology, p:.210-213. Springer, Berlin.

Owen D., A.P. Williams, G.W. Griffith and P.J.A. Withers. 2015. Use of commercial bio-inoculants to increase agricultural production through improved phosphorus acquisition. Applied Soil Ecology. 86: 41-54.

Page, A.L., R.H. Miller and D.R. Keeney. 1982. Methods of Soil Analysis. $2^{\text {nd }}$ Ed., American Society of Agronomy, Madison, WI., USA.

Phillips, J.M. and D.S. Hayman. 1970. Improved procedures for clearing and staining parasitic and vesiculararbuscular mycorrhizal fungi for rapid assessment of infection. Trans.Br.Mycol.Soc. 55: 158-161.

Rahim N., A. Sadegh, J.R. Mohammad, M. Abbas and M. Amir. 2013. Effects of inoculation with Azotobacter chroococcum and Pseudomonas putida on yield and some of the important agronomic traits in barley (Hordeum 
vulgar L.). Inter. J. Agron. Plant Production. 4 (7), 1602 1610.

Rizzolo A.C., J. Baldo and A. Polesello. 1993. Application of high performance liquid chromatography to the analysis of niacin and biotin in Italian almond cultivars, J. Chromatoghraphy,553: 1-2.

Roopa B., C. Maya and H.K. Makari. 2012. Effect of different PGPR strain along with rhizobium on nodulation and chickpea productivity. Asian J. Exp. Biol. Sci. 3: 424426.

Runyan, C.W. and P. D'Odorico. 2013. Positive feedbacks and bistability associated with phosphorus-vegetationmicrobial interactions. Advan. Water Res. 52: 151-164.

Shaalan M.N. 2005. Influence of bio-fertilizers and chicken manure on growth, yield and seeds quality of (Nigella sativa L.) plants. Egypt. J. Agric. Res., 83: 811-828.

Sharma S.B., R.Z. Sayyed, M.H. Trivedi and T.A. Gobi. 2013. Phosphate solubilizing microbes: sustainable approach for managing phosphorus deficiency in agricultural soils. Springer Plus. 2:587.

Shaukat K., S. Affrasayab and S. Hasnain. 2006b. Growth responses of Triticum aestivum to plant growth promoting rhizobacteria used as a bio-fertilizer. Res. J. Microbiology, 1(4): 330-338.

Singh M. and T.N. Prakash. 2012. Characterization of phosphate solubilizing bacteria in sandy loam soil under chickpea cropping system. Indian J. Microbiol. 52: 167173.
Sushanta S., S. Bholanath, M. Sidhu, P. Sajal and D.R. Partha. 2014. Grain yield and phosphorus uptake by wheat as influenced by long-term phosphorus fertilization. Afric. J. Agric. Res. 9(6): 607-612.

Teakle, N.L. and S.D. Tyerman. 2010. Mechanisms of Cltransport contributing to salt tolerance. Plant, Cell and Environ., 33: 566-589.

Wang P., Y. Wang, B. Shu, J.F. Liu, R.X. Xia. 2015. Relationships between Arbuscular Mycorrhizal Symbiosis and Soil Fertility Factors in Citrus Orchards Along an Altitudinal Gradient. Pedosphere 25: 160-168.

Xu, F., J. Zhu, S. Cheng, W. Zhang and Y. Wang. 2010. Effect of 5-aminolevulinic acid on photosynthesis, yield, nutrition and medicinal values of kudzu (Pueraria phaseoloides) Tropical Grasslands., 44: 260-265.

Yousufinia, M., A. Ghasemian, O. Safalian and A. Asadi. 2013. The effect of $\mathrm{NaCl}$ on the growth and $\mathrm{Na}+$ and $\mathrm{K}+$ content of barley (Hordeum vulgare L.) cultivars Annals of Biological Research, 4(1): 80-85.

Zahir A Z., M. Arshad and A. Khalid. 1998. Improving maize yield by inoculation with plant growth promoting rhizobacteria. Pakistan J. Soil Sci., 15: 7-11.

Zhang L., J. Fan, W. Niu and Y. Jing. 2011. Isolation of phosphate solubilizing fungus (Aspergillus niger) from Caragana rhizosphere and its potential for phosphate solubilization. Shengtai Xuebao/Acta Ecol. Sin. 31: 75717578 . 


\section{الملخص العربي}

أهمية فطريات الميكوريزا والبكتريا المذيبة للفسفور على زيادة الفوسفات المتاح للشعير فى أرض جيرية

$$
\text { منى مرسى الثاذلى و نهى موسى عبد الحميد و عمرو محمود عبد الجواد }
$$

أجريت تجربتين حقليتين لدراسة تأثير فطريات الفوسفات. وقد أدى التلقيح المزدوج من فطريات الميكوريزا الميكوريزا الجذرية و البكتيريا المذيبة للفوسفور على تيسر واتئين البكتريا المذيبة للفوسفور (VAM+PDB) الى زيادة معنوية

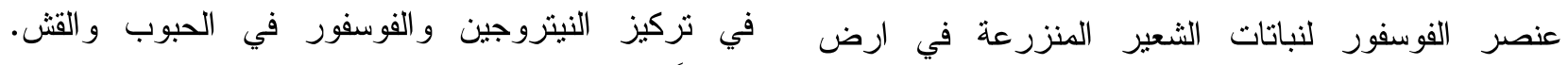

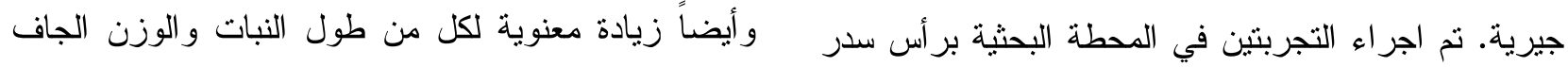

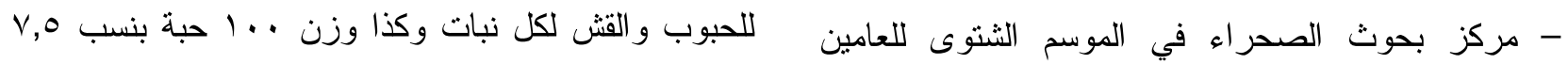
10 التسميد الحيوى التلقيح بفطريات الميكوريزا (VAM) م معنوية لمحصول الحبوب و والقش و المحصول البيولوجى

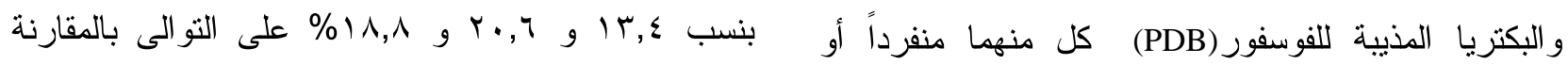

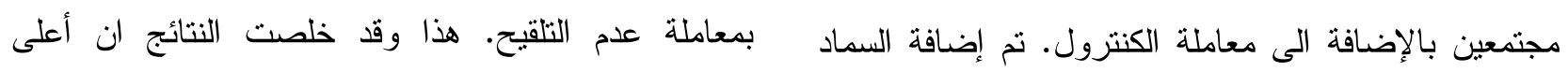

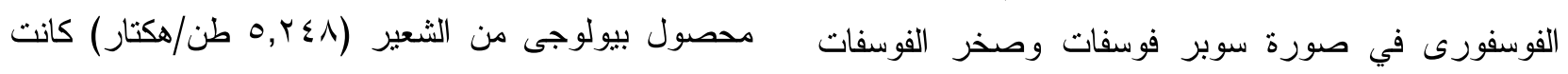

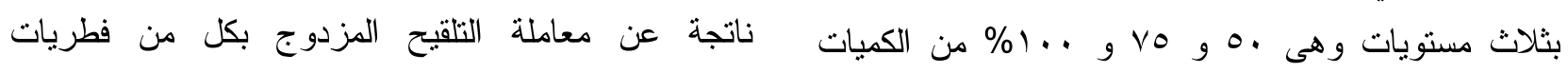

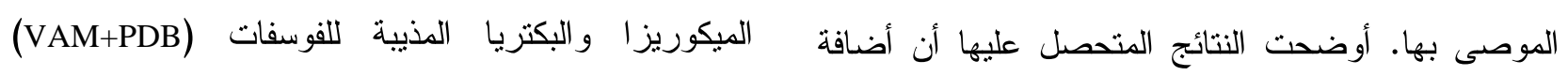

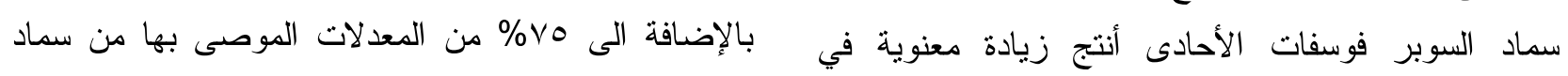

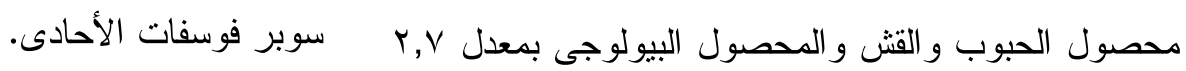

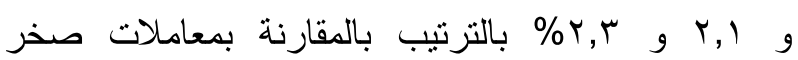

